\title{
2006-1586: TOLERANCE FOR AMBIGUITY: AN INVESTIGATION ON ITS EFFECT ON STUDENT DESIGN PERFORMANCE
}

\section{Susan Mohammed, Pennsylvania State University}

Susan Mohammed is an Associate Professor of Industrial and Organizational Psychology at The Pennsylvania State University. She received her PhD from The Ohio State University. Her research focuses on teams and decision-making, with a special emphasis on team mental models, team composition and decision styles. Her published work appears in journals such as Organizational Behavior and Human Decision Processes, Personnel Psychology, Journal of Management, Journal of Organizational Behavior, and Organizational Research Methods. She currently serves on the editorial board for Organizational Behavior and Human Decision Processes.

\section{Gül Okudan, Pennsylvania State University}

Gül E. Okudan is an Assistant Professor of Engineering Design at The Pennsylvania State University. She received her Ph.D. from University of Missouri-Rolla. Her research interests include intelligent shop floor control, manufacturing strategy modeling and measurement, solid modeling, product design, and product design teams. Her published work appears in journals such as Journal of Engineering Design, Journal of Engineering Education, European Journal of Engineering Education and Technovation. She is a member of ASEE and ASME. She is also a National Research Council-US AFRL Summer Faculty Fellow of the Human Effectiveness Directorate for 2002, 2003 and 2004.

\section{Madara Ogot, Pennsylvania State University}

Madara Ogot is an Associate Professor in Engineering Design and Mechanical Engineering at The Pennsylvania State University. He is the co-author, along with Gül Okudan of an introductory engineering design text, Engineering Design: A Practical Guide. His current research interests include design under uncertainty, stochastic optimization and innovative design. He received his BSE from Princeton in 1987, and his MS and Ph.D. from the Pennsylvania State University in 1989 and 1991, respectively. 


\title{
Tolerance for Ambiguity: An Investigation on Its Effect on Student Design Performance
}

\begin{abstract}
Design is a common activity for most disciplines in engineering. Therefore, introductory engineering courses are developed to include design activities as the main driver for the curriculum. Despite this fact, however, it can not be concluded that the implementation of design teaching is done in a way conducive to student learning. While there could be several reasons for this, this paper specifically investigates the effect of tolerance for ambiguity on student design performance. An analysis of the data collected for this investigation reveals the beneficial effects of higher tolerance for ambiguity on increased efficacy, satisfaction, and conflict resolution in the context of an open-ended, team-based, industry-sponsored engineering design project.
\end{abstract}

Keywords: Design teams, tolerance for ambiguity, efficacy, design performance.

\section{Introduction}

Because "engineering programs must demonstrate that their graduates have: ... an ability to design a system, component, or process to meet desired needs," and "an ability to function in multi-disciplinary teams....", design is integrated to the engineering curricula through the use of design teams. In many cases, this integration also uses industry-sponsored design projects. Most of the industry-sponsored design project applications are at the capstone design level, and many examples of these are documented in the literature ${ }^{2-9}$. Capstone design courses are used to ease the transition from the education environment to industry by providing design problems originating from industry, and a setting for graduating engineers to work in design teams. Industry-sponsored projects not only provide a link between practicing engineers and graduating students, but also give students a deeper understanding for how they will use their discipline specific knowledge and skills in industry. Thus, although a few concerns are raised ${ }^{11-12}$, there is overwhelming evidence for the success of capstone design courses that employ industrysponsored design projects ${ }^{2-10}$.

Among the benefits of industry sponsored design projects the following four items are frequently mentioned: (1) because of their inherent layers of complexity students confront issues that stretch them beyond textbooks, (2) because these projects are done for a company that cares about the outcome students feel more motivated, (3) their scope generally, demands teamwork and therefore, students learn project management, and (4) these projects give students exposure to industry cultures and practices. Accordingly, the use of industry-sponsored projects throughout the curriculum is advocated, and they are increasingly being used at the freshmen level ${ }^{13-17}$.

At the first-year level, industry-sponsored projects can create a better understanding for what engineers do while instilling basic engineering and design principles. Despite the potential benefits outlined above, however, the outcomes of these projects can be mixed in multiple ways. 
From a faculty point of view, (1) each industry-sponsored project is assigned only once, limiting faculty's ability to improve upon the first offering and refine the project, which (2) increases the amount of course preparation for each course offering. From a student's point of view, motivation and self-efficacy may decrease when (1) the project domain (e.g., electrical engineering) is not directly related to their chosen major (e.g., chemical engineering), (2) the projects are perceived to be skewed toward a particular gender (e.g., masculine- or feminineoriented), and (3) students may evaluate abstract, ambiguous projects from industry negatively because they lack the tools to address open-ended problem solving. These issues may be particularly problematic for introductory design offerings taken by first year students who are making critical decisions about whether to stay in the engineering major.

Many schools have adopted a common, design-driven engineering curriculum for all disciplines at the first year ${ }^{18}$. Therefore, all first year engineering students in these schools take their first engineering course in a setting where no discipline specific knowledge and skill development is expected. Rather, developing an understanding for engineering in general with its fundamental principles is sought. Frequently, however, when industry-sponsored projects are integrated into the curriculum, the projects are too narrowly defined limiting the integration of multidisciplinary view points to design solutions ${ }^{19}$. In such a situation, because of the potential mismatch in a student's chosen engineering discipline and the industry-sponsored design project domain, some students may feel less motivated compared to the ones who feel the project is closely related to the engineering discipline in which they would like to get their degree.

A similar motivation loss can occur, if the context of the industry sponsored design project is seen as more familiar to one gender compared to the other. Although potential issues due to the gender orientation of the design project domain have been pointed out ${ }^{21-23}$, gender differences in design performance of first-year engineering students have been studied only in isolated cases ${ }^{15}$, 21. However, how the potential gender orientation of an industry-sponsored design project might impact students' design performance and the effectiveness of the project for providing a design learning environment have not been assessed.

Finally, while the complexities of teaching with industry-sponsored projects due to their openended nature have been discussed (e.g., project management, unequal contributions from design team members) ${ }^{24-27}$, no study so far has investigated the students' readiness for solving openended design problems such as industry sponsored design problems at the first-year level.

Overall, while symptomatic evidence exists for the above mentioned issues related to the integration of industry sponsored design projects at the first-year level, there is no comprehensive, conclusive, research based evidence or prescriptive guidelines to help faculty in this regard. Because there is an increasing trend in adopting these types of projects at the first year level ${ }^{13-17}$, we address these issues. In this paper, we focus on the tolerance for ambiguity and its implications for a design team in an educational setting.

\section{Ambiguity of the Project and Student Readiness for Open-Ended Problem Solving}

The current first year engineering design teaching included in the study features two design projects, the first of which is guided and fairly straight-forward, while the second is industry- 
sponsored and more open-ended. Instructor observations reveal that students generally seem less comfortable with the industry-sponsored project because it is less defined than the first project. In addition, industry-sponsored projects across semesters have differed with respect to their level of abstraction and ambiguity. For example, during the semester in which students were assigned a fume hood controller design project we have received lower than usual course ratings. Among the reasons for this may be the abstractness of dealing with concepts such as air-flow and the difficulty in visualizing what was required. Indeed, open-ended comments from students during this semester repeatedly refer to the confusing and ambiguous nature of the project and the need for more detail and clarity. Sample comments include, "Give us a better defined problem," "It was hard to tell what needed to be done," "Maybe explain thoroughly what the hell we are doing instead of having everyone ask questions." These reactions suggest that project ambiguity may lead to decreased self-efficacy and student learning if interventions are not conducted to mitigate negative effects.

Ambiguity refers to perceived insufficiency of information and is used to describe decisions for which the odds of an uncertain event are not precisely known ${ }^{28}$. Much has been written regarding making decisions under conditions of ambiguity or uncertainty, and models have been proposed to describe this process (e.g., reference 29). In addition to the level of ambiguity inherent in a task or project, individuals can be categorized as ambiguity averse, ambiguity seeking, or ambiguity indifferent ${ }^{28}$. Tolerance for ambiguity is a personality variable defined as the tendency to perceive ambiguous situations as desirable $\mathrm{e}^{30}$. Need for closure is a related construct referring to a desire for definitive knowledge, for a firm answer to a question and an aversion to ambiguity ${ }^{31}$.

Clearly, design tasks will differ with regard to their level of abstractness and ambiguity, and first year engineering students will display varying degrees of readiness to deal with open-ended problem solving. Insufficient attention has been given to these issues in the literature, despite their potential importance for building self-efficacy as well as increased student learning and performance.

\section{Self- and Collective-Efficacy}

The concept of efficacy was introduced into the literature by Bandura ${ }^{32}$ and was originally defined at the individual level of analysis. Self-efficacy is the belief in one's capacity to perform a particular task or situation-specific self-confidence ${ }^{33}$, and it has been strongly linked to individual performance. For teams, however, it is appropriate to examine collective efficacy, which refers to a group's belief in its capability to perform ${ }^{34}$. While self-efficacy informs collective efficacy through the coordination of individual effort, goals, and skills ${ }^{35}$, the two constructs are empirically distinct. With the shift to team-based work in many organizations, researchers have established that group efficacy is a meaningful and measurable group attribute $^{34,36-37}$. In fact, a recent meta-analysis of 67 empirical studies found that collective efficacy had a positive relationship with performance $(\mathrm{p}=0.41$; reference 37$)$. Although selfefficacy has been studied with regard to gender issues in an engineering context (e.g., references 38-39), less attention has been given to the construct of collective efficacy. In addition, tolerance for ambiguity and efficacy relation has not been investigated in an engineering design context. 


\section{Proposed Model and Hypotheses}

To address the research needs discussed above, the focus of this paper was to investigate the relationships between personality-based tolerance for ambiguity, the ambiguity of the task, collective efficacy, and team design performance in an engineering context. This focus will contribute to a much-needed understanding of team dynamics in engineering educational settings where design teams are heavily utilized. The specific objective was to investigate collective efficacy as a mediator of the relationship between tolerance for ambiguity and design team performance, and as a function of the level of task ambiguity.

As discussed previously, engineering students in our sample completed two design projects over the course of the semester. Because the first project was guided and straightforward, whereas the second was industry-sponsored and much more open-ended, it was expected that tolerance for ambiguity would have a greater impact on the variables measured for the second project. In other words, the personality trait of tolerance for ambiguity was proposed to be more relevant when the project demands involved a higher degree of uncertainty and abstractness. Specifically, the following hypotheses were proposed:

(1). Individuals with higher tolerance for ambiguity will report higher levels of:
a. self-efficacy,
b. collective efficacy,
c. satisfaction with the team, and
d. conflict resolution.

(2). Task ambiguity will impact the relationships examined in this study such that tolerance for ambiguity will be more positively related to variables examined for the more open-ended design project (Project \#2) as opposed to the more straightforward design project (Project \#1)

(3). Collective efficacy will be positively correlated with team performance. Previous research (e.g., reference 37) has found this relationship, and it is expected to be replicated in the proposed study.

\section{Data Collection and Results}

During the fall of 2003, data were collected in several sections of an introductory engineering design course, which is required for all freshmen engineering majors. Participants included 144 students ( 99 males and 45 females). Two surveys were administered over the course of the semester, one after the completion of the first design project (midpoint of the semester), and the other after the completion of the second design project (end of the semester). Although students had completed the requirements of their projects when they filled out the questionnaires, they did not yet know their project scores. The surveys measured tolerance for ambiguity, individual selfefficacy, collective efficacy, satisfaction with their team, and conflict resolution. Tolerance for ambiguity was only assessed once (at time 2), whereas the other variables were assessed at two points in time. 
Tolerance for ambiguity was measured using the Multistimulus Types Ambiguity Tolerance - I (MSTAT-I), a 22-item measure ${ }^{40}$ which comprehensively addresses characteristics of ambiguous stimuli and reactions to perceived ambiguity. Sample items include, "I generally prefer novelty over familiarity" and "I enjoy tackling problems which are complex enough to be ambiguous." The internal consistency reliability (Cronbach's alpha) of the MSTAT-I was .89 in the current sample. Self-efficacy was measured by asking students to estimate the grade that they would individually earn in the course. Collective efficacy was measured by means of a 4-item scale with an alpha of .76. Sample items in the collective efficacy scale include, "I have real confidence in my group's ability to perform well on projects" and "The members of this group have excellent skills." Team satisfaction was measured with a 3 -item scale (alpha $=.86$ ), including the item, "I am satisfied with this team compared to teams I have been on in the past." Team conflict resolution was measured with a 3 -item scale (alpha $=.87$ ), and a sample item is "We effectively deal with interpersonal friction/personality clashes in my group." Performance was assessed via instructor grades for the team projects.

Results revealed no gender significant gender effects for tolerance for ambiguity; therefore, neither males nor females were more likely to report a greater degree of tolerance for ambiguity. Table 1 compares the correlations between tolerance for ambiguity and the other variables measured in this study across the two design projects.

Table 1. A Comparison of Correlation Between Tolerance for Ambiguity and Other Measures

\begin{tabular}{|l|l|l|}
\hline $\begin{array}{l}\text { Relationship between tolerance for } \\
\text { ambiguity and: }\end{array}$ & $\begin{array}{l}\text { Design Project 1 (Straightforward, } \\
\text { guided project) }\end{array}$ & $\begin{array}{l}\text { Design Project 2 } \\
\text { (Open-ended, industry- } \\
\text { sponsored project) }\end{array}$ \\
\hline Self-efficacy & $-.26(\mathrm{p}=.01)-$ significant & $-.23(\mathrm{p}=.02)-$ significant \\
\hline Collective efficacy & $.06(\mathrm{p}=.58)-$ not significant & $.27(\mathrm{p}=.01)$ - significant \\
\hline Satisfaction with the Team & $.12(\mathrm{p}=.26)-$ not significant & $.19(\mathrm{p}=.05)$ - significant \\
\hline Conflict Resolution & $-.04(\mathrm{p}=.72)-$ not significant & $.24(\mathrm{p}=.01)$ - significant \\
\hline
\end{tabular}

NOTE: entries are bivariate correlations.

As shown in Table 1, the only negative correlations that resulted were for self-efficacy. Contrary to predictions, students with higher tolerance for ambiguity reported less self-efficacy regarding their individual performance in the course for both design projects. Supportive of hypotheses 1b, $1 \mathrm{c}$, and $1 \mathrm{~d}$, individuals with higher tolerance for ambiguity reported higher levels of collective efficacy, satisfaction with the team, and conflict resolution, but only for the second design project. Therefore, hypothesis 2 was generally supported in that tolerance for ambiguity exerted more of an influence for the more open-ended project as opposed to the more straightforward project. This pattern of results reveals the beneficial effects of higher tolerance for ambiguity on increased collective efficacy, satisfaction, and conflict resolution in the context of an openended, team-based, industry-sponsored engineering design project.

Hypothesis 3 predicted that collective efficacy would be positively correlated with team performance. Results revealed that there was not a significant relationship between collective efficacy and team performance for either the first $(\mathrm{r}=-.05, \mathrm{p}=.58)$ or second $(\mathrm{r}=.06, \mathrm{p}=.67)$ design projects. This finding is contrary to previous research that has found a positive relationship between the two variables, but may indicate that predicting team performance in this setting may be more complex than relying on a single predictor (e.g., collective efficacy). Rather, 
many variables may contribute, and relationships may involve interactions between predictors. In addition, it should also be noted that the sample size for performance for the second design project was only 54 because we were only able to gain access to team performance scores for a sub-sample of the class sections in which data was collected. Therefore, a low sample size might also have contributed to the lack of significant findings.

Although we expected that tolerance for ambiguity would be related to collective efficacy (supported for the second design project) and that collective efficacy would be related to performance (not supported), we also examined the direct relationship between tolerance for ambiguity and performance. Correlational analyses revealed that the students with a higher tolerance for ambiguity tended to perform lower on the first design project, although the correlation was only marginally significant $(\mathrm{r}=-.16, \mathrm{p}=.09)$. Interestingly, because this design project was straightforward, those with a higher tolerance for ambiguity may have experienced negative results because their personality disposition was in conflict with task demands. For the second design project, there was no significant relationship between tolerance for ambiguity and team performance $(\mathrm{r}=.07, \mathrm{p}=.64)$. Again, a much lower sample size for second project grades may have contributed to the lack of findings.

\section{Conclusions}

These preliminary findings partially support our hypotheses. Based on the fall 2003 data, the beneficial effects of higher tolerance for ambiguity on increased efficacy, satisfaction, and conflict resolution in the context of an open-ended, team-based, industry-sponsored engineering design projects are evident. Future work related to this work will focus on collecting data from a larger sample and with varying project types.

\section{References}

1. ABET (2002). http://www.abet.org/images/Criteria/E1\%200304\%20EAC \%20 Criteria \% 2011-15-02.pdf, accessed on April 10, 2003.

2. Coleman, R.J. and Shelnutt, J.W. (1995). Fostering university/industry partnerships through sponsored undergraduate design. Proceedings of the Frontiers in Education Conference, v. 1, p. 8-11.

3. Ray, J.L. (2003). Industry-academic partnerships for successful capstone projects. Proceedings of the Frontiers in Education Conference, v. 3, p. S2B24-S2B29.

4. Magleby, S.P., Sorensen, C.D., and Todd, R.H. (1991). Integrated product and process design: a capstone course in mechanical and manufacturing engineering. Proceedings of the Frontiers in Education Conference. TwentyFirst Annual Conference. Engineering Education in a New World, p. 469-74.

5. Freckleton, J.E. (1995). Student design projects in a design for manufacturing course. ASEE Annual Conference Proceedings, v. 1, Investing in the Future, p. 633-638.

6. Moore, D. and Berry, F. (1999). Industrial sponsored design projects addressed by student design teams. Proceedings of the 29th Annual Frontiers in Education Conference, pt. 1, p. 11B2/15-20.

7. Conn, A.F. and Sharpe, W.N., Jr. (1993). An industry-sponsored capstone design course. Proceedings of the Frontiers in Education. Twenty-Third Annual Conference. Engineering Education: Renewing America's Technology, p. 493.

8. Bales, W.J., Counce, R.M., Dodds, H.L., Edmondson, A.J., Ford, R.E., Raman, D.R., Speckhart, F.H., Shannon, T.E., Tompkins, F.D. and Yoder, R.E. (1997). Industry-sponsored student design teams in engineering at the University of Tennessee, Proceedings. Frontiers in Education 1997, 27th Annual Conference. Teaching and Learning in an Era of Change, pt. 1, p 310-15 vol.1.

9. Ruud, C. and Deleveaux, V.J. (1997). Developing and conducting an industry based capstone design course. Proceedings of the Frontiers in Education Conference, v 2, 1997, p.644-647.

10. Bradford, D.T., (1991). Beneficial aspects of industrial sponsorship of design projects, National Conference Publication - Institution of Engineers, Australia, n 91 pt 7, Improving the Manufacturing Climate, p 35-39. 
11. Dekker, D.L., (1997). Issues when using company sponsored projects to provide a design experience for students, Proceedings of the Frontiers in Education Conference, v 1, p 304-306.

12. Magleby, S.P., Todd, R.H.; Pugh, D.L.; Sorensen, C.D. (2001). Selecting appropriate industrial projects for capstone design programs. International Journal of Engineering Education, v17, n 4-5, 2001, p 400-5.

13. Mourtous, N.J., Furman, B.J. (2002). Assessing the effectiveness of an introductory engineering course for freshmen, 32nd Annual Frontiers in Education Conference Proceedings, pt.2, pF3b-12-16, v. 2.

14. Broduer. D.R., Young, P.W., Blair, K.B. (2002). Problem-based learning in aerospace engineering education. Proceedings of the ASEE Annual Conference \& Exposition, Session 2202.

15. Moskal, B.M., Knecht, R., Lasich, D. (2002). Engineering design: Using a scoring rubric to compare the products of teams that differ in gender composition. Proceedings of the ASEE Annual Conference \& Exposition, Session 2630.

16. Hirsch, P., Anderson, J., Colgate, J.E., Lake, J., Shwom, B. and Yarnoff, C. (2002). Enriching freshman design through collaboration with professional designers. Proceedings of the ASEE Annual Conference \& Exposition, Session 1353.

17. Design Projects, http://www.ecsel.psu.edu/design-projetcs/, viewed on July $6^{\text {th }}, 2004$.

18. Sheppard, S., Jenison, R. (1997). Freshman engineering design experiences: An organization framework. International Journal of Engineering Education, 13(3), p 190-197.

19. Amon, C.H., Finger, S., Siewiorek, D.P., and Smailagic, A. (1995). Integration of design education, research, practice at Carnegie Mellon University: A Multi-disciplinary course in wearable computer design. Proceedings of the FIE Conference, p.4a1.14-17.

20. Interviews with faculty teaching Introductory Engineering Design at Penn State.

21. Okudan, G.E., Bilén, S.G. and $\mathrm{Wu}, \mathrm{X}$. (2003). Gender orientation of the design task: Product domain and familiarity issues. International Conference on Engineering Design ICED, August 19-22, 2003, Stockholm, Sweden.

22. Okudan, G.E. and Bilén, Sven. G. (2003). Effect of gender orientation of the design task on team performance: A preliminary study. ASEE Annual Conference \& Exposition, June 21-24, 2003, Nashville, TN.

23. Okudan, G.E. (2002). On the gender orientation of the product design task. 32nd ASEE/IEEE Frontiers in Education Conference, November 6-9, 2002, Boston, MA.

24. Okudan, G.E. and Devon, R. (2002). Embedding engineering management to product design education. ASEE Annual Conference \& Exposition, June 16-19, 2002, Montreal, Canada.

25. Koen, B.V. (1994). Toward a strategy for teaching engineering design. Journal of Engineering Education, 38, 3, 193-201.

26. Fentiman, A.W. and Demel, J.T. (1995). Teaching students to document a design project and present the results, Journal of Engineering Education, 84, 4, 329, 333.

27. Moor, S.S. and Drake, B.D. (2001). Addressing Common Problems in Engineering Design Projects: A Project Management Approach. Journal of Engineering Education, 90, 3,389-395.

28. Kahn, B. E. and Sarin, R. K. (1988). Modeling ambiguity in decisions under uncertainty. Journal of Consumer Research, 15, 265-272.

29. Einhorn, H. J. and Hogarth, R. M. (1986). Decision making under ambiguity. Journal of Business, 59(4), pp. 225-250.

30. Furnham, A. and Ribchster, T. (1995). Tolerance for ambiguity: A review of the concept, its measurement, and applications. Current Psychology: Developmental, Learning, Personality, Social, 14, 179-199.

31. Kruglanski, A. W. and Webster, D. M. (1996). Motivated closing of the mind: "seizing" and "freezing." Psychological Review, 103, 263-283.

32 Bandura, A. (1977). Self-efficacy: Toward a unifying theory of behavioral change. Psychosocial Review, 64, 191-215.

33. Bandura, A. (1997). Self-efficacy: The exercise of control. New York: Freeman.

34. Gibson, C. B. (1999). Do they do what they believe they can? Group efficacy and group effectiveness across tasks and cultures. Academy of Management Journal, 42, 2, 138-152.

35. Gist, M. E. \& Mitchell, T. R. (1992). Self-efficacy: A theoretical analysis of its determinants and malleability. Academy of Management Review, 17, 2, 472-485.

36. Gibson, C. B., Randel, A. E., \& Earley, P. C. (2000). Understanding group efficacy: An empirical test of multiple assessment methods. Group and Organization Management, 25, 67-97.

37. Gully, S. M., Incalcaterra, K. A., Joshi, A., \& Beaubien, J. M. (2002). A meta-analysis of team efficacy, potency, and performance: Interdependence and level of analysis as moderators of observed relationships. Journal of Applied Psychology, 87, 5, 819-832. 
38. Besterfield-Sacre, M., Moreno, M., Shuman, L.J. and Atman, C.J. (2001). Gender and ethnicity differences in freshmen engineering student attitudes: A cross-institutional study. Journal of Engineering Education, 90, 4, 477-489.

39. Malicky, D. (2003). A literature review on the under-representation of women in undergraduate engineering: Ability, self-efficacy, and the "chilly climate." Proceedings of the 2003 American Society for Engineering Education Annual Conference and Exposition, June 21-25, Nashville, TN.

40. McLain, D. L. (1993). The MSTAT-I: A new measure of an individual's tolerance for ambiguity. Educational and Psychological Measurement, 53, 183-189. 